\title{
Introduction to the Special Issue on "Aging and Migration in Europe”
}

Isabelle Albert', Dieter Ferring', and Frieder R. Lang²

'Research Unit INSIDE, University of Luxembourg, Esch-sur-Alzette, Luxembourg

${ }^{2}$ Institute of Psychogerontology, University of Erlangen-Nuremberg, Nuremberg, Germany

Aging and migration have become key issues in many European societies today, as an unprecedented number of firstgeneration immigrants of the big immigration waves of the 1960s and 1970s are currently approaching retirement age.Originally, such migration to an economically prosperous country with better job opportunities was often associated with the expectation to return to the country of origin after some years of hard work - and after having accumulated enough wealth to restart a better life "back home." While these expectations were often held equally by the receiving societies and by the migrants, they soon emerged as the so-called "myth of return" (see e.g., Bolognani, 2007). In fact, while only a small proportion of immigrants permanently returns to their countries of origin, even after longer periods abroad (see e.g., Baykara-Krumme, 2013, for a discussion of Turkish immigrants in several European countries), a large proportion of aging immigrants intend to stay in their receiving countries after retirement or to commute between the country of origin and the host country, a trend demonstrated for various immigrant groups in several European countries (see, e.g., Attias-Donfut, Tessier, and Wolff, 2005, aswell asDeCoulon\&Wolff, 2005, for international immigrants in France; Bolzmann, Fibbi, \& Viol, 2006, for Italian and Spanish immigrants in Switzerland).

Full text available at http://econtent.hogrefe.com/doi/full/10.1024/1662-9647/a000142 